\title{
Penyuluhan Perilaku Hidup Bersih Dan Sehat (PHBS) Di TKK Dan SDK Santo Bavo Kota Madiun
}

\author{
Agus Purwanto \\ Prodi Biologi, Universitas Katolik Widya Mandala Surabaya Kampus Kota Madiun, Jl. Manggis 15-17, Madiun, 63131 \\ E-mail: aguspurwanto@widyamandala.ac.id
}

\begin{abstract}
The lack of facilities plays an important role in realizing a clean and healthy life, but it is not an obstacle for the participants and other school members of SDK Santo Bavo to be able to habituate their daily healthy lifestyle. The results of the initial survey conducted by SDK Santo Bavo students had never been given any education or counseling on the importance of clean and healthy living habits. Based on this, it is necessary to do it through counseling and training on PHBS (Healthy Day-to-Life Behavior) for students in and other residents in TKK and SDK Santo Bavo. The activity is carried out through counseling and training on how to wash hands properly with boiled water of betel leaf as a substitute for soap which has antibacterial properties. Online counseling activities through instructional videos have succeeded in increasing partners' knowledge about making green betel leaf (Piper betle L) boiled water which has antibacterial properties and steps on how to wash with boiled green betel leaf water as a substitute for soap (CTPS) which is good and correct.
\end{abstract}

Keywords — : daily healthy behavior, green betel, antibacterial, learning videos.

\section{PENDAHULUAN}

\section{A. Latar Belakang}

Demam Berdarah Dengue (DBD) merupakan penyakit menular yang disebabkan oleh virus dengue yang disebarkan oleh nyamuk. Pada jaman dahulu, Demam Berdarah Dengue (DBD) disebut penyakit "break-bone" karena menyebabkan nyeri sendi dan otot di mana tulang terasa retak. Demam berdarah yang ringan dapat menyebabkan demam tinggi, ruam, serta nyeri otot bahkan sendi. Bila parah juga dikenal sebagai Dengue Hemorrhagic Fever, dapat berakibat perdarahan serius, penurunan tekanan darah secara tiba-tiba (shock), dan kematian (Aprilia L. Samiadi, dkk, 2017).

Kebersihan diri adalah upaya individu dalam memelihara kebersihan diri, meliputi kebersihan rambut, gigi, mulut, mata, telinga, kuku, kulit, dan tangan. Pemeliharaan kebersihan diri sangat menentukan status kesehatan seseorang yang secara yang secara sadar dan atas inisiatif pribadi menjaga kesehatan dan mencegah terjadinya penyakit.

Kesadaran akan pentingnya kebersihan dan kesehatan harus ditanamkan sejak dini. Untuk merubah suatu keadaan menjadi lebih baik haruslah dimulai dari diri sendiri terlebih dahulu. Membiasakan hidup bersih dan sehat dapat dilakukan oleh semua orang tidak terkecuali oleh anak-anak kecil.

Setiap orang menginginkan keadaan yang sehat dalam melakukan aktivitas hidup mereka, maka diperlukan upaya untuk memelihara dan meningkatkan derajat kesehatannya sendiri. Salah satu cara untuk mendukung upaya tersebut adalah dengan menjaga higienitas masing-masing individu, yaitu perilaku individu menjaga kebersihan diri dalam berbagai aktivitas seharihari. Salah satu kegiatan hygiene pribadi yang dapat diterapkan dalam kehidupan sehari-hari adalah dengan melakukan kegiatan mencuci tangan (Ariyani, 2017).

Mencuci tangan dapat dilakukan dengan berbagai produk yang mengandung antiseptik yang digunakan untuk membunuh bakteri di tangan misalnya dengan penggunaan sabun cuci tangan atau hand sanitizer. Salah satu bahan tradisional yang memiliki sifat antimikroba adalah daun sirih hijau (Piper betle L.). Mencuci tangan dengan air rebusan daun sirih hijau dapat mengurangi efek samping yang tidak diinginkan seperti iritasi kulit yang disebabkan adanya kandungan alkohol dan bahan aktif lainnya pada sabun cuci tangan ataupun handsinitizer (Ariyani, 2017).

Kondisi bersih dapat dicapai dengan mengubah perilaku dari yang tidak bersih menjadi perilaku hidup bersih dan menciptakan lingkungan bersih di rumah, dan sekolah (Kementerian Kesehatan RI, 2011). Oleh karena itu dalam kegiatan pengabdian kepada masyarakat ini sangat perlu dilakukan sosialisasi tentang perilaku hidup bersih terutama pada lingkungan peserta didik di sekolah dasar dan warga sekolah yang lain. Fokus kegiatan pengabdian adalah memberikan pengetahuan yang benar tentang pembiasaan perilaku hidup bersih sehari (PHBS) dan memberikan pelatihan cara mencuci tangan pakai sabun (CTPS) dan penggunaan obat trasdisional yang berkhasiat antibakteri dan antijamur secara baik dan benar.

TKK dan SDK Santo Bavo Madiun adalah Sekolah Dasar Swasta di bawah naungan Yayasan Yohanes Gabriel Perwakilan IV Madiun beralamat di jl. Bumi Jaya No. 60 Madiun dengan jumlah jumlah guru dan siswa 8, siswa laki-laki 47, siswa perempuan 36, dan rombongan belajar 6. Sarana dan prasarana sekolah dan jumlah sanitasi yang kurang baik dan keberadaan peserta didik dari orang tua yang kurang beruntung secara ekonomi. Minimnya fasilitas memang mempunyai peran yang 
Website : http://dayamas.unmermadiun.ac.id/index.php/dayamas

penting dalam mewujudkan hidup bersih dan sehat, tetapi bukan menjadi hambatan untuk peserta dan warga sekolah yang lain di TKK dan SDK Santo Bavo dapat melakukan pembiasaan perilaku hidup sehat sehari-hari.

Hasil survei yang telah dilakukan peserta didik SDK Santo Bavo belum pernah dilakukan edukasi atau penyuluhan tentang pentingnya perilaku hidup bersih dan sehat. Oleh karena itu dalam kegiatan pengabdian kepada masyarakat ini sangat perlu dilakukan penyuluhan tentang PHBS (Perilaku Hidup Bersih dan Sehat) terhadap peserta didik di dan warga lain di TKK dan SDK Santo Bavo. Fokus kegiatan pengabdian kepada masyarakat ditujukan untuk membentuk kebiasaan mencuci tangan yang benar dengan sabun dan tanaman-tanaman herbal, misalnya daun sirih hijau (Piper betle L) dan kayu secang (Caesalpinia sappan L) yang berkhasiat antibakteri, serta daun murbei hitam (Morus nigra) dan daun trembesi (Samanea saman) yang berkhasiat anti jamur.

\section{B. Tujuan Kegiatan}

Melalui kegiatan edukasi ini tujuannya adalah sebagai berikut:

1. Memberikan pengetahuan dalam bentuk penayangan video pembelajaran secara daring tentang konsep perilaku hidup bersih dan sehat (PHBS) dan cara cuci tangan yang baik dan benar (CTPS) untuk mencegah terjadinya penyakit patogen yang menular di TKK dan SDK Santo Bavo Kelurahan Rejomulyo Kecamatan Kartoharjo Madiun.

2. Memberikan pelatihan melalui penayangan video pembelajaran secara daring tentang mencuci tangan yang baik dan benar rebusan daun sirih hijau sebagai salah salah satu tanaman yang berkhasiat antibakteri, misalnya daun sirih hijau (Piper betle L) di TKK dan SDK Santo Bavo Kelurahan Rejomulyo Kecamatan Kartoharjo Madiun

\section{Manfaat Kegiatan}

1. Meningkatnya pengetahuan tentang perilaku hidup bersih dan sehat (PHBS) bagi warga sekolah (guru/tenaga, tenaga pendidik, dan siswa sekolah) TKK dan SDK Santo Bavo Madiun.

2. Dihasilkannya video edukasi tentang pembuatan rebusan tanaman tradisional berkhasiat antibakteri serta cara cuci tangan yang baik dan benar.

\section{TINJAUAN PUSTAKA}

\section{A. Perilaku Hidup Bersih Sehat}

Berdasarkan Kementerian Kesehatan RI (2011), dinyatakan bahwa Perilaku Hidup Bersih dan Sehat (PHBS) adalah sekumpulan perilaku yang dipraktikkan atas dasar kesadaran sebagai hasil pembelajaran, yang menjadikan seseorang, keluarga, kelompok atau masyarakat mampu menolong dirinya sendiri di bidang kesehatan dan berperan aktif dalam mewujudkan kesehatan masyarakat. PHBS adalah upaya memberikan pengalaman belajar bagi perorangan, keluarga, kelompok dan masyarakat, dengan membuka jalur komunikasi, memberikan informasi dan melakukan edukasi, guna meningkatkan pengetahuan, sikap dan perilaku, melalui pendekatan Advokasi, Bina Suasana (Social Support) dan Gerakan Masyarakat (Empowerment) sehingga dapat menerapkan cara-cara hidup sehat, dalam rangka menjaga, memelihara dan meningkatkan kesehatan masyarakat (Depkes RI, 2011).

Pemberdayaan masyarakat harus dimulai dari rumah tangga atau keluarga, karena rumah tangga yang sehat merupakan asset atau modal pembangunan di masa depan yang perlu dijaga, ditingkatkan dan dilindungi kesehatannya.

Beberapa anggota rumah tangga mempunyai masa rawan terkena penyakit menular dan penyakit tidak menular, oleh karena itu untuk mencegah penyakit tersebut, anggota rumah tangga perlu diberdayakan untuk melaksanakan PHBS. Anak merupakan kelompok yang paling rentan terserang penyakit. Permasalahan perilaku kesehatan pada anak terutama usia dini (usia setelah kelahiran sampai dengan usia sekitar 6 tahun) biasanya berkaitan dengan kebersihan perorangan dan lingkungan. Penyakit yang sering muncul akibat rendahnya perilaku hidup bersih dan sehat antara lain cacingan, diare, sakit gigi, sakit kulit, gizi buruk, dan lain sebagainya (Khoirudin, dkk., 2015).

\section{B. Kepentingan Mencuci Tangan yang Baik dan Benar}

Kebersihan tangan merupakan hal yang terpenting dari kewaspadaan tiap orang dan merupakan metode yang paling awal dan efektif dalam mencegah penularan mikroba patogen yang berhubungan dengan kesehatan (WHO, 2008). Usaha untuk menjaga tangan agar selalu bersih adalah salah satu langkah penting untuk mencegah penyakit dan mencegah penularan penyakit ke orang lain (CDC, 2015).

Mencuci tangan dengan sabun di air yang mengalir merupakan salah satu cara paling efektif mencegah penyebaran penyakit menular, termasuk virus corona covid-19. Hal ini juga sudah ditegaskan oleh Badan Kesehatan Dunia (WHO). Cara ini bahkan lebih efektif membunuh virus dibanding memakai hand sanitizer.

Berdasarkan Pusat Pengendalian dan Pencegahan Penyakit tahun 2016 dinyatakan bahwa cuci tangan dengan sabun merupakan cara yang sangat efektif untuk mereduksi keberadaan mikroba tangan (CDC, 2016). Adanya pencanangan aksi cuci tangan untuk melawan kasus resistensi terhadap antibiotik (WHO, 2017), diharapkan setiap warga masyarakat dunia untuk membiasakan mencuci tangan dengan sabu dan air mengalir untuk mengantisipasi meluasnya kasus resistensi mikrobia terhadap antibiotik. 
Website : http://dayamas.unmermadiun.ac.id/index.php/dayamas

Penerapan pembiasaan mencuci tangan yang baik dan benar bukanlah satu-satunya cara untuk melawan penyebaran virus, tetapi mencuci tangan sampai bersih dengan sabun mampu mematikan virus yang ada di tangan. Kegiatan mencuci tangan dengan sabun dan air mengalir adalah salah satu tindakan mudah dan murah yang dapat dilakukan. Sekitar $98 \%$ penyebaran penyakit menular bersumber dari tangan. Oleh karena itu menjaga kebersihan tangan adalah hal yang penting dilakukan.

\section{Tanaman Herbal Sumber Antimikroba}

Salah satu bahan tradisional yang memiliki sifat antimikroba adalah daun sirih hijau (Piper betle L.). Mencuci tangan dengan air rebusan daun sirih hijau dapat mengurangi efek samping yang tidak diinginkan seperti iritasi kulit yang disebabkan adanya kandungan alkohol dan bahan aktif lainnya pada sabun cuci tangan ataupun handsinitizer (Ariyani, 2017).

Beberapa hasil penelitian telah banyak dipublikasikan terkait dengan tanaman-tanaman berkhasiat sebagai sumber antibakteri dan antijamur. Beberapa tanaman yang digunakan sebagai antibakteri misalnya jambu biji, jambu mente, daun sembung (Yuana dkk, 2016 dan Ghinan dkk, 2016). Hasil penelitian Hastuti dkk (2012) menunjukkan daya antibakteri ekstrak daun murbei (Morus alba) terhadap Staphylooccus aureus (85\%) dan Shigella dysenteriae (95\%). Penelitian yang lain telah menunjukkan aktivitas antibakteri murbei hitam (Morus nigra) terhadap bakteri penyebab jerawat Propionibacterium acnes dan Staphylococcus epidermisdis (Urwatul dkk, 2018).

Ekstrak tanaman krokot yang diuji terhadap Aspergillus niger, Rhizopus artocarpi dan Fusarium sp. menunjukkan aktivitas antijamur terhadap Fusarium sp., Sedangkan ekstrak etanol dan kloroform dari tanaman krokot yang sama menghambat pertumbuhan Rhizopus artocarpi (Banerje dan Mukherjee, 2002).

\section{III.HASIL DAN PEMBAHASAN}

\section{A. Uraian Kegiatan}

Kegiatan pengabdian kepada masyarakat ini diperlukan untuk mensosialisasikan tentang perilaku hidup bersih terutama pada lingkungan warga sekolah (guru/tenaga, tenaga pendidik, dan siswa sekolah) TKK dan SDK Santo Bavo Madiun. Fokus kegiatan pengabdian dilakukan dengan memberikan pengetahuan yang benar tentang pembiasaan perilaku hidup bersih dan sehat (PHBS) dan memberikan pelatihan cara mencuci tangan dengan air rebusan daun sirih hijau (CTPS) dengan baik dan benar.

Kegiatan penyuluhan perilaku hidup bersih sehari (PHBS) dilaksanakan pada kelompok responden warga sekolah (guru/tenaga, tenaga pendidik, dan siswa sekolah) TKK dan SDK Santo Bavo, dengan jumlah responden sebanyak 33 orang.

Kegiatan penyuluhan diawali dengan tes awal pengisian kuesioner secara daring melalui fasilitas google form, pada tanggal 24 November 2020. Kegiatan tes awal (pretes) dilakukan sebelum responden diberikan video pembelajaran. Selanjutnya kegiatan dilanjutkan dengan pemberian penyuluhan video pembelajaran untuk membantu responden untuk memahami pengetahuan tentang cara pembuatan infusa daun sirih hijau (Piper betle $\mathrm{L}$ ) dan cara mencuci tangan dengan baik dan benar menggunakan air rebusan daun sirih hijau sebagai cairan antibakteri.

Setelah proses pemberian pembelajaran (video pembelajaran) selesai dilakukan selanjutnya mitra diberikan kuesioner kembali secara daring melalui google form sebagai postes untuk mengetahui tingkat pengetahuan tentang pembuatan air rebusan daun sirih hijau (Piper betle L) dan 6 (enam) langkah cara mencuci dengan infusa sirih hijau yang baik dan benar.

Sedangkan target luaran yang belum dilaksanakan terkait dengan publikasi artikel ilmiah akan dilaksanakan setelah pelaporan kegiatan pengabdian kepada masyarakat.

\section{B. Uraian Perubahan pada Sasaran}

Kegiatan pengetahuan kepada masyarakat di TKK dan SDK Santo Bavo Madiun adalah meningkatnya pembiasaan perilaku hidup bersih sehari-hari dari peserta didik dan warga sekolah yang lain di lingkungan sekolah, khususnya cara cuci tangan menggunakan air rebusan sirih hijau sebagai pengganti sabun (CTPS) dan cara pembuatan infusa sirih hijau yang berkhasiat antibakteri. Selain itu dihasilkannya video edukasi tentang pembuatan rebusan daun tanaman sirih hijau yang berkhasiat antibakteri serta cara cuci tangan yang baik dan benar dengan air rebusan daun tanaman sirih hijau (CTPS) yang berkhasiat antibakteri.

Berdasarkan data hasil pengisian kuesioner selama pretes dan postes, seluruh mitra peserta penyuluhan di TKK dan SDK Santo Bavo Madiun sebanyak 33 responden adalah sebagai berikut:

\section{Hasil Pengisian Kuesioner Pertanyaan ke-1}

Hasil pretes menunjukkan bahwa pemahaman mitra terkait dengan bagian tubuh yang harus dibersihkan rutin setiap hari cukup baik $(84.84 \%)$. Selanjutnya pemahaman pengetahuan tersebut meningkat setelah postes melalui proses pembelajaran (video pembelajaran) sebesar $93.93 \%$. 
Website : http://dayamas.unmermadiun.ac.id/index.php/dayamas

Tabel 1. Persentase Jawaban Benar Terhadap Pertanyaan Kuesioner Sebelum dan Sesudah Pembelajaran

\begin{tabular}{|l|c|c|}
\hline \multicolumn{1}{|c|}{ Daftar Pertanyaan } & $\begin{array}{c}\text { Jawaban Benar } \\
\text { Pretes (\%) }\end{array}$ & $\begin{array}{c}\text { Jawaban Benar } \\
\text { Postes (\%) }\end{array}$ \\
\hline $\begin{array}{l}\text { Bagian tubuh manakah yang harus } \\
\text { dibersihkan rutin setiap hari? }\end{array}$ & 84.84 & 93.93 \\
\hline $\begin{array}{l}\text { Tanaman apakah apakah yang dapat } \\
\text { digunakan untuk menghilangkan kuman? }\end{array}$ & 100 & 100 \\
\hline $\begin{array}{l}\text { Bahan apa yang digunakan untuk membuat } \\
\text { rebusan daun sirih hijau? }\end{array}$ & 100 & 100 \\
\hline $\begin{array}{l}\text { Berapa jumlah air yang digunakan untuk } \\
\text { membuat air rebusan daun sirih hijau? }\end{array}$ & 54.54 & 69.69 \\
\hline $\begin{array}{l}\text { Berapa derajat celcius suhu yang digunakan } \\
\text { untuk merebus daun sirih hijau? }\end{array}$ & 39.39 & 84.84 \\
\hline $\begin{array}{l}\text { Berapa langkah mencuci tangan yang } \\
\text { benar? }\end{array}$ & 72.72 & 78.78 \\
\hline $\begin{array}{l}\text { Kapan air rebusan daun sirih digunakan saat } \\
\text { mencuci tangan? }\end{array}$ & 72.72 & 84.84 \\
\hline Kapan sebaiknya mencuci tangan? & 90.90 & 93.93 \\
\hline
\end{tabular}

2. Hasil Pengisian Kuesioner Pertanyaan ke-2

Hasil pengisian pretes mitra terhadap pertanyaan tanaman yang dapat digunakan untuk menghilangkan kuman sangat baik (100\%), dan jawaban benar tetap dipertahankan setelah postes sebesar 100\%. Hal ini kemungkinan mitra telah mendapatkan pengetahuan yang baik selama proses pembelajaran di sekolah.

3. Hasil Pengisian Kuesioner Pertanyaan ke-3

Hasil pretes dan postes terhadap pertanyaan kuesioner ke-3 dapat diketahui bahwa mitra sudah memiliki pengetahuan yang baik tentang bahan yang digunakan untuk membuat rebusan daun sirih hijau, masing-masing sebesar 100\%.

4. Hasil Pengisian Kuesioner Pertanyaan ke-4

Jawaban mitra yang diperoleh dari pretes dan postes terhadap pertanyaan jumlah air yang seharusnya digunakan untuk membuat air rebusan daun sirih hijau diketahui bahwa peningkatan pemahaman mitra meningkat sekitar 15\% (dari $54.54 \%$ menjadi $69.69 \%$ ). Hasil ini kemungkinan disebabkan sulitnya memahami tentang takaran yang tepat untuk menghasilkan air rebusan dengan dosis yang paling baik untuk mematikan kuman.

5. Hasil Pengisian Kuesioner Pertanyaan ke-5

Peningkatan pengetahuan mitra terjadi cukup tinggi terhadap jawaban kuesioner pretes dan postes, masing-masing sebesar $39.39 \%$ dan $84.84 \%$. Hasil pemahaman mitra meningkat sekitar $45 \%$, hal ini menggambarkan bahwa mitra telah memahami dengan baik terkait dengan suhu yang paling baik digunakan untuk membuat rebusan daun sirih hijau.

6. Hasil Pengisian Kuesioner Pertanyaan ke-6

Berdasarkan hasil pretes dan postes terhadap pertanyaan kuesioner ke-4 terkait dengan jumlah langkah yang harus dilakukan untuk mencuci tangan dengan air rebusan daun sirih yang hanya meningkat sebesar 6\% (dari 72.72 menjadi 78.78), menunjukkan bahwa mitra kurang memahami tentang jumlah langkah CTPS dengan air rebusan sirih hjau yang baik dan benar.

\section{Hasil Pengisian Kuesioner Pertanyaan ke-7}

Berdasarkan hasil pretes dan postes terhadap pertanyaan kuesioner ke-7 tentang penggunaan air rebusan daun sirih saat mencuci tangan peningkatan pemahaman mitra sebesar $12 \%$ (dari 84.84 menjadi 72.72 ). Pengetahuan mitra tentang penggunaan air rebusan sirih hijau cukup baik, yaitu dilakukan setelah pembasahan tangan dengan air mengalir.

8. Hasil Pengisian Kuesioner Pertanyaan ke-8

Hasil pretes dapat diketahui bahwa pengetahuan awal mitra terkait dengan kapan harus mencuci dengan tangan baik (90.90 3\%). Selanjutnya setelah dilakukan proses pembelajaran melalui edukasi video hasilnya hanya meningkat sebesar 3\%. Hal ini menunjukkan bahwa pemahaman mitra sudah baik tentang kapan kegiatan mencuci tangan sebaiknya dilakukan.

pada hari Sabtu, 9 November 2019 ini diawali dengan pembukaan oleh Ibu RT setempat dan dilanjutkan oleh nara sumber. 
Website : http://dayamas.unmermadiun.ac.id/index.php/dayamas

\section{IV.KESIMPULAN DAN SARAN}

\section{A. Kesimpulan}

Berdasarkan evaluasi kegiatan penyuluhan ini dapat disimpulkan hasil sebagai berikut:

1. Peningkatan pengetahuan mitra mengenai terkait dengan perilaku hidup bersih dan sehat (PHBS).

2. Peningkatan pengetahuan mitra tentang cara pembuatan air rebusan sirih hijau sebagai pengganti sabun untuk mencuci tangan (CTPS) dengan baik dan benar

3. Dihasilkannya video edukasi tentang pembuatan air rebusan daun sirih hijau yang berkhasiat antibakteri.

B. Saran

1. Diperlukannya kegiatan untuk memantau kepastian praktek baik mitra dalam menerapkan kegiatan mencuci tangan dengan memanfaatkan air rebusan daun tanaman yang berkhasiat antibakteri yang benar untuk meningkatkan derajad kesehatan masyatrakat.

2. Diperlukan kegiatan penyuluhan pelatihan secara daring atau luring dan penggunaan alat peraga (video pembelajaran) yang lebih informatif dan menarik untuk meningkatkan pemahaman dan pemotivasian.

\section{DAFTAR PUSTAKA}

Ariyani, A. 2017. Perbandingan Jumlah Angka Bakteri Antara Mencuci Tangan Menggunakan Sabun Dengan Hand Sinitizer Pada Mahasiswa Jurusan Analis Kesehatan Poltekes Kemenkes Kendari. KTI. Kendari: Jurusan Analisis Kesehatan. Politeknik Kesehatan Kendari.

Banerje, G and A. Mukherjee. 2002. Biological Activity of A Common Weed Portulaca oleracea L Antifungal Activity. Acta Botanica Hungarica 4 (3-4), 205208.

Banun, T. S. (2016). Hubungan antara Pengetahuan PHBS dengan Pola Hidup Sehat Siswa di SD Tamanan. Jurnal Pendidikan Guru Sekolah Dasar . Edisi 14.

Centers for Disease Control and Prevention (CDC). 2015. When and How to Wash Your Hands: http://www.cdc.gov/handwashing/when-howhandwashing.html, diakses (diakses 7 Desember 2020).

Centers for Disease Control and Prevention (CDC). 2016. Show Me the Science -When to Use Hand sanitizer'. http://www.cdc.gov/ handwashing/show-methe-science-handsanitizer.html\#washing. Diakses 7 Desember 2020.

Ghinan Sholih, M. dan Qowiyah, A. 2016. Pengujian Aktivitas Antidiare Infusa Daun Sembung (Blumea balsamifera) Pada Mencit Jantan Galur Swiss Webster. Skripsi. Karawang : Universitas Singaperbangsa Karawang.

Hastuti, U.S., Oktantia, A., dan Khasanah, H.N. 2012. Daya Antibakteri Daun dan Buah Murbei (Morus alba L.) terhadap Staphylococcus aureus dan Shigella dysenteriae. Skripsi. Malang : Biologi FMIPA Universitas Negeri Malang.

Kementeian Kesehatan RI. (2011). Pedoman Pembinaan Perilaku Hidup Bersih dan Sehat. Jakarta: Kementrian Kesehatan.

Khoiruddin, Kirnantoro, \& Sutanta. (2015). Tingkat Pengetahuan Berhubungan dengan Sikap Cuci Tangan Bersih Bersih Pakai Sabun Sebelum dan Setelah Makan Pada Siswa SDN Ngebel, Tamantirta, Kasihan, Bantul, Yogyakarta. Journal Ners And Midwifery Indonesia, Vol. 3 No. 3

Urwatul, Wusqo, dan Budiman, A. 2018. Aktivitas Antibakteri, Antioksidan, dan Antiinflamasi Murbei Hitam (Morus nigra L.). Farmaka Suplemen volume 16 nomor 2 . 